\title{
Crown-To-Root Ratios in Terms of Length, Surface Area and Volume: A Pilot Study of Premolars
}

\author{
Relaciones de la Corona y Raíz Dentaria en Términos de Longitud \\ Superficie y Volumen: Un Estudio Piloto de Dientes Premolares
}

Lin Liu*; Hongbo Li**; Tong Zha***; Yuxuan Gao*; Jing Guo*; Xiaoyu Wang* \& Xuesheng Li*

LIU, L.; LI, H.; ZHAO, T.; GAO, Y.; GUO, J.; WANG, X. \& LI, X. Crown-to-root ratios in terms of length, surface area and volume: A pilot study of premolars. Int. J. Morphol., 34(2):465-470, 2016.

SUMMARY: The objective of this study was to construct three-dimensional (3D) images of premolars to measure the length, surface area and volume of crown and root and to analyze the mathematical relation among crown-to-root ratios in terms of length, surface area and volume. Twenty-five premolars were scanned using micro-computed tomography (micro CT) in vitro to build 3D models. The long axis and enamelo-cemental junction of each tooth were determined with the help of Geomagic Studio software, and the length, surface and volume of crown and root were measured. The crown-to-root ratios in terms of length, surface and volume were calculated and the relationship among length, surface area and volume of crown and root as well their ratios were analyzed using SPSS software. The interrelationship among crown length $(\mathrm{x})$, surface area $(\mathrm{y})$ and volume $(\mathrm{z})$ could be expressed as $\mathrm{z}=-808.20+124.80 \mathrm{x}+3.35 \mathrm{y}-5.59 \mathrm{x}^{2}-$ $0.14 x y+3.47 y^{2^{*}} 10^{-4}\left(R^{2}=0.99\right)$ and that of root length $\left(x_{1}\right)$, surface area $\left(y_{1}\right)$ and volume $\left(z_{1}\right)$, as $z_{1}=-207.50+13.87 x_{1}+1.75 y_{1}+5.03 x_{1}{ }^{2 *} 10-$ ${ }^{2}-8.05 \mathrm{x}_{1} \mathrm{y}_{1} * 10^{-2}+2.58 * 10^{-3} \mathrm{y}_{1}^{2}\left(\mathrm{R}^{2}=0.93\right)$. The correlation among crown-to-root ratio in length $\left(\mathrm{x}_{2}\right)$, crown-to-root ratio in surface area $\left(\mathrm{y}_{2}\right)$ and crown-to-root ratio in volume $\left(\mathrm{z}_{2}\right)$ could be expressed in $\mathrm{z}_{2}=-4.48^{*} 10^{-2}-1.25 \mathrm{x}_{2} * 10^{-2}+1.20 \mathrm{y}_{2}+3.29 \mathrm{x}_{22}-5.05 \mathrm{x}_{2} \mathrm{y}_{2}+2.00 \mathrm{y}_{2}{ }^{2}\left(\mathrm{R}^{2}=0.96\right)$. The length, surface area and volume of crown and root of premolars share a close relationship, while, a definite mathematical relation could be observed amongst their ratios. Crown to root ratio in terms of length, surface and volume, may provide a novel multi-criterion method for evaluating tooth function.

KEY WORDS: Bicuspid; Tooth crown; Tooth root.

\section{INTRODUCTION}

Crown-to-root ratio refers to the ratio of the portion of the tooth above the alveolar bone to that which lies below it, as determined by radiograph (The glossary of prosthodontic terms, 2005). Short dental roots resulting in unfavorable crown to root ratios can affect the prognosis of teeth (Holtta et al., 2004) and increases the periapical stress. This factor is critical for tooth restoration especially after bone loss periodontal trauma is caused when the crown-to-root ratio in length rises beyond certain limit (Nyman \& Lang, 1994). Clinicians have used crown to root ratios as a parameter to decide if teeth should be restored or employed as abutments in dental prostheses, based on empirical guidelines with no scientific data (Greenstein \& Cavallaro, 2011). Apart from the crownto-root ratio, periapical stress and function depend on periodontal ligament areas and root volume. While the area of periodontal ligament reflects the combination between root and alveolar bone, the root volume reflects the portion of encysted and supported root by alveolar bone (Anderson et al., 1983; Dunlap \& Gher, 1985; Gher \& Dunlap, 1985; Klock et al., 1993; Pan et al., 2004).

Several methods are used for the measurement of tooth surface area in vitro, including weight-shifting (Klock et al.), area-segmentation (Dunlap \& Gher; Gher \& Dunlap), digital radiographs (Anderson et al.; Pan et al.) and estimation of the periodontal ligament (The glossary of prosthodontic terms). However, these measurements are not quite precise, and the operations are too complicated, and not suitable for regular clinical practice. Tooth volume is usually measured in vitro by traditional Archimedes method. Currently, there is no specific method for the measurement of crown and root volume of the teeth. The development of three-dimensional

\footnotetext{
* The People's Liberation Army General Hospital Oral Medical Center, Beijing, China.

** The People's Liberation Army General Hospital Department of Stomatology, Beijing, China.

${ }^{* * *}$ University of Chinese Academy of Sciences, Beijing, China.
} 
(3D) imaging and image processing technologies and soft wares has enabled precise analysis of tooth shape and the measurement of the periodontal ligament, which can be widely, applied in future clinical practice.

Premolar is a commonly-used abutment tooth for prosthesis. The aim of the present study is to explore the interrelationship among the length, surface and volume of crown and root of premolars by 3D imaging and measuring methods. Additionally, the mathematical relation among the crown-to-root ratios in length, surface and volume will be analyzed.

\section{MATERIAL AND METHOD}

Study population. Patients suffering from periodontal diseases $(n=25)$ were included in the study. Informed consent was taken from the participants before extraction of teeth. The study protocol was approved by the ethical committee of our hospital dental, Beijing, China (NO. S2014-011-01), and was conducted as per the declaration of Helsinki, and all participants provided written informed consent.

Selection of teeth. Teeth without any deformity, decay, severe wear or fillings were selected and disinfected with $2 \%$ sodium hypochlorite for 24-hour to remove soft tissue attachments on the tooth surface. Dental calculus and deposits were removed through ultrasonic scaling, and stored in $10 \%$ formaldehyde solution.

Tooth scanning and 3D remodeling. Tooth scanning was performed by GE Explore Locus Micro-CT (GE Healthcare, USA) with the layer thickness of $46 \mu \mathrm{m}$. The dental image (DICOM data) was then uploaded into Minics software. The digital models of tooth surface shape were rebuilt using triangle methods.

Analysis and measurements of teeth. The 3D tooth models were uploaded into Geomagic Studio software (Geomagic, Morrisville, NC, USA), to conduct conical fitting. The long axis of tooth was determined by calculating the function of the central axis of the cone. In Geomagic Studio software, The enamelo-cemental junction, was determined through manual delineation according to its surface characteristics and was considered as the boundary between crown and root by the software. The extremes of the tooth were taken as crown- point and root-point. The average projection of the points on enamelo-cemental junction onto the long axis was calculated. The length of crown and root was determined, as well as crown-to-root ratio, which equaled to the ratio of crown length and root length.

The 3D tooth model was divided into two parts based on the enamelo-cemental junction. The surface area of crown and root was calculated by the software. The crown-to-root ratio was calculated as the ratio of crown surface area to root surface area.

The 3D tooth model was divided into two closed parts according to the curved surface of enamelo-cemental junction. The volume of crown and root was calculated, and the crown-to-root ratio in volume was calculated based on these values.

Statistical Analysis. Statistical analyses were performed using matlab software. The correlation and the mathematical relationship among the length, surface and volume of crown and root were analyzed.

\section{RESULTS}

Digital model of the teeth. The $3 \mathrm{D}$ digital model of the tooth is shown in Figure 1. Enamelo-cemental junction and the divided margins are depicted in Figure 2. The length, surface area and volume of both crown and root were measured in the 25 teeth, and the crown-to-root ratios in length, surface and volume were determined (Table I).
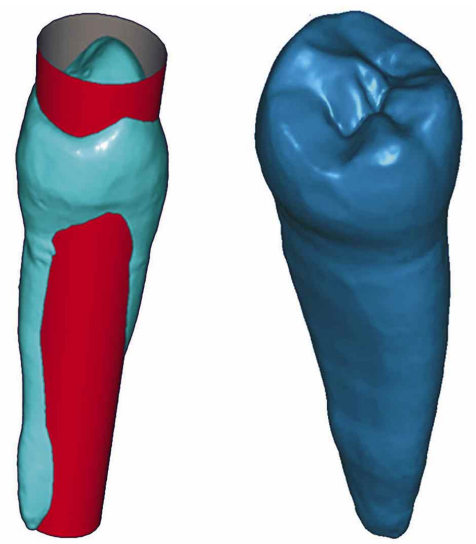

Fig. 1. Fitted 3D model of tooth. The 3-D images of the tooth were uploaded into Geomagic software to identify the most suitable cone. The centralaxis of the cone was calculated as the long axis of the tooth.
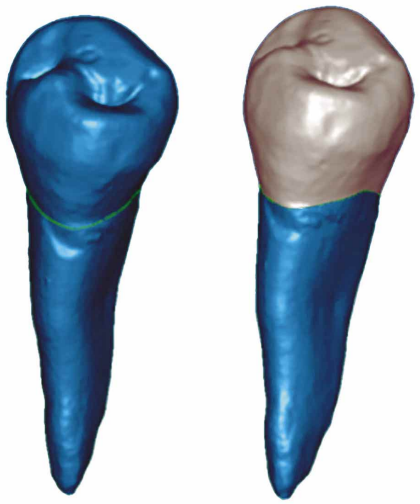

Fig. 2. Divided amelodentinal margin. The 3-D images of the tooth was uploaded into Geomagic software, and the borderline between the enamel and the cementum, which separate the tooth crown from tooth root, was decided according to the images and the tooth. 
Table I. The length, surface area and volume of crown and root and their ratio in 25 premolars.

\begin{tabular}{lcr}
\hline & \multicolumn{2}{c}{$\mathbf{n = 2 5}$} \\
\cline { 2 - 3 } & Average & SD \\
\hline Crown length $(\mathrm{mm})$ & 9.11 & 1.02 \\
Crown surface area $\left(\mathrm{mm}^{2}\right)$ & 228.62 & 41.74 \\
Crown volume $\left(\mathrm{mm}^{3}\right)$ & 352.08 & 94.03 \\
Root length $(\mathrm{mm})$ & 14.10 & 2.20 \\
Root surface area $\left(\mathrm{mm}^{2}\right)$ & 237.33 & 48.28 \\
Root volume $\left(\mathrm{mm}^{3}\right)$ & 291.95 & 87.91 \\
Crown-to-root ratio in length & 0.65 & 0.08 \\
Crown-to-root ratio of surface area & 0.98 & 0.19 \\
Crown-to-root ratio in volume & 1.25 & 0.31 \\
\hline
\end{tabular}

The length, surface area and volume of crown and root were measured in 25 premolar teeth using 3D micro-computed tomography. The crown to root ratio was calculated for each parameter.
Correlation between length surface area and volume of root and crown of teeth. A linear relationship was observed among crown length (x), surface area (y) and volume (z) (Fig. 3 ) and root length $\left(x_{1}\right)$, surface area $\left(y_{1}\right)$ and volume $\left(z_{1}\right)$ (Fig. $4)$. The relationship between crown length, surface area and volume could be expressed as in $\mathrm{z}=-808.20+124.80 \mathrm{x}+3.35 \mathrm{y}$ $-5.59 x^{2}-0.14 x y+3.47 y^{2 *} 10-4$. R-square equaled to 0.99 and that of root length, surface area and volume as $z_{1}=-207.50$

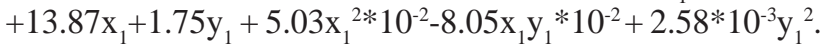
$\mathrm{R}$-square equaled to 0.93 .

A second-order correlation presented among crownto-root ratio in length $\left(\mathrm{x}_{2}\right)$, crown-to-root ratio in surface area $\left(\mathrm{y}_{2}\right)$ and crown-to-root ratio in volume $\left(\mathrm{z}_{2}\right)$, which could be expressed in $\mathrm{z}_{2}=-4.48 * 10^{-2}-1.25 \mathrm{x}_{2} * 10^{-2}+1.20 \mathrm{y}_{2}+3.29 \mathrm{x}_{2}{ }^{2}$ $5.05 \mathrm{x}_{2} \mathrm{y}_{2}+2.00 \mathrm{y}_{2}^{2}$ (Fig. 5). R-square equaled to 0.96 .

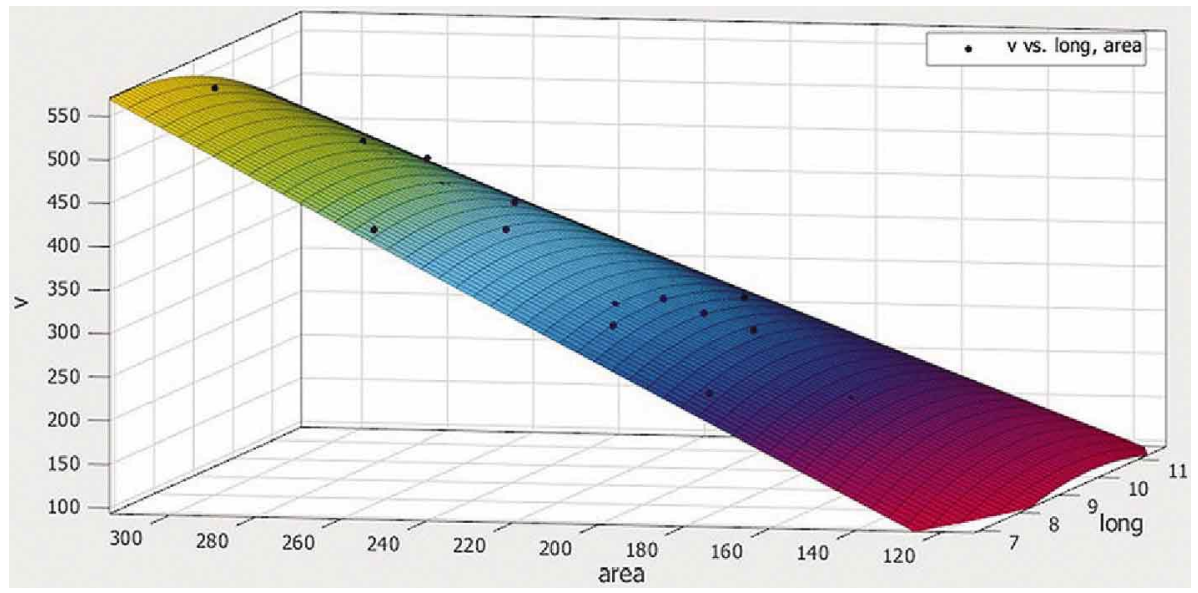

Fig. 3. Relationship among crown length $(\mathrm{x}, \mathrm{mm})$, surface area $\left(\mathrm{y}, \mathrm{mm}^{2}\right)$ and volume $\left(\mathrm{z}, \mathrm{mm}^{3}\right)$. The relationship among the length of the tooth crown, surface area, and volume could be expressed by a formula of second derivative, namely $z=-808.20+124.80 x+3.35 y-5.59 x^{2}-0.14 x y+3.47 y^{2}$ $* 10^{-4}, \mathrm{R}^{2}=0.99$.

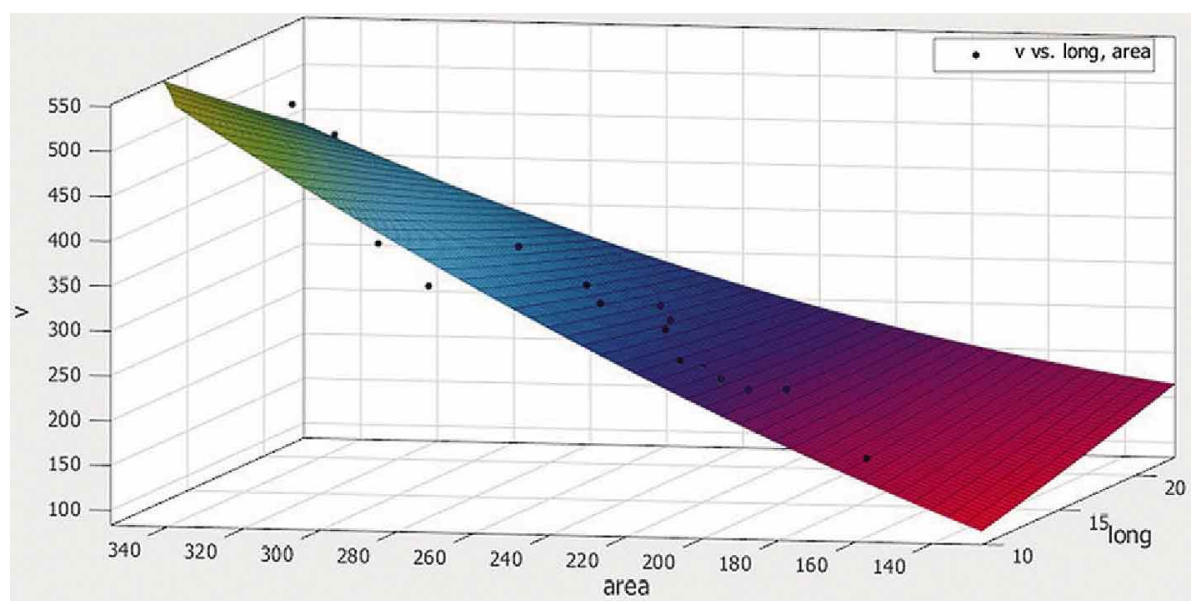

Fig. 4. Relationship among root length $\left(\mathrm{x}_{1}, \mathrm{~mm}\right)$, surface area $\left(\mathrm{y}_{1}, \mathrm{~mm}^{2}\right)$ and volume $\left(\mathrm{z}_{1} \mathrm{~mm}^{3}\right)$. The relationship among the root length, surface area, and volume could be expressed by a formula of second derivative, namely $\mathrm{z}_{1}=-207.50+13.87 \mathrm{x}_{1}+1.75 \mathrm{y}_{1}+$ $5.03 \mathrm{x}_{1}^{2 *} * 10^{-2}-8.05 \mathrm{x}_{1} \mathrm{y}_{1} * 10^{-2}+2.58 * 10^{-}$ ${ }^{3} \mathrm{y}_{1}{ }^{2}, \mathrm{R}^{2}=0.93$. 


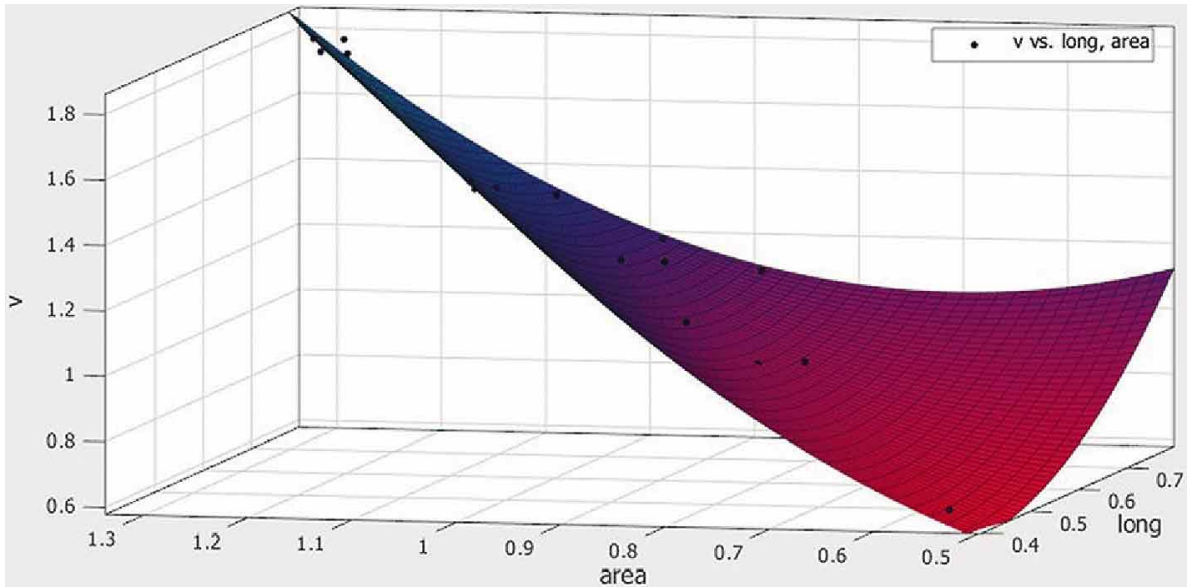

Fig. 5. Relationship among crown-to-root ratio in length $\left(\mathrm{x}_{2}\right)$, crown-to-root ratio in surface area $\left(\mathrm{y}_{2}\right)$ and crown-to-root ratio in volume $\left(\mathrm{z}_{2}\right)$. The relationship among the crown-to-root ratio in length, crown-to-root ratio in surface area $\left(\mathrm{y}_{2}\right)$ and crown-to-root ratio in volume could be expressed in a third order function formula, namely $\mathrm{z}_{2}=-4.48 * 10^{-2}-1.25 \mathrm{x}_{2} * 10^{-2}+1.20 \mathrm{y}_{2}+3.29 \mathrm{x}_{2}{ }^{2}-5.05 \mathrm{x}_{2} \mathrm{y}_{2}$ $+2.00 \mathrm{y}_{2}^{2}, \mathrm{R}^{2}=0.96$.

\section{DISCUSSION}

The evaluation of tooth function governs the treatment and prognosis of dental diseases. Assessments of alveolar bone support, tooth mobility, root morphology, tooth angles, occlusion and the structure of tooth tissues contribute to tooth function. But the criteria for the overall assessment of tooth morphology and function have not been clearly defined so far (Anderson et al.; Gher \& Dunlap; Pan et al.). Periodontal ligament surface areas and crown-to-root ratio are both important clinical indexes in evaluating the functions of natural as well as abutment teeth.

A periodontal ligament (PDL) is a set of connective tissue fibers that attach the alveolar bones to roots of teeth and is most important for tooth mobility. It transmits functional and orthodontic forces to the alveolar bone and the resulting stresses or strains within the PDL and bone control the process of bone-modeling (Melsen, 2001; Storey, 1973). PDL can widen to take extra traumatic forces like tooth occlusion. It is generally considered that the support of periodontal tissues depends on the geometric area of periodontal ligaments. During the past decades, several measurement studies on periodontal ligaments of natural teeth have been reported with varied results (Yamamoto et al., 2006). These include weightshifting, area-segmentation, digital radiographs and estimation of the periodontal ligament (Anderson et al.; Dunlap \& Gher; Gher \& Dunlap; Klock et al.; Pan et al.; Yamamoto et al.). All the above methods could only be used in the measurement under in vitro conditions and could not be applied in clinical practice. In the present study, 3D tooth models were built based on Micro-CT scanning data for the first time. The length, surface and volume of crown and root were calculated with the help of software.

High resolution micro-CT is an innovative and nondestructive device to produce a true three-dimensional (3D) reconstruction of an object. 3D measuring methods are being used in the measurement of tooth length, surface and volume, which will contribute for the overall assessment of tooth function with multiple indexes.

Crown-to-root ratio is important for the choice of abutment teeth for dentures and the judgment of prognosis (Pan et al.). However; it is only a linear measurement and has limitations in clinical assessment. Abutment teeth and the bone around them carry additional load from the lost teeth. During the assessment of abutment teeth, clinicians mainly evaluate the support from alveolar bones and periodontal ligament surface areas, which are both three-dimensional quantities. Since most teeth are conical, measurement of tooth length, as a single-dimensional measuring value, is not enough to evaluate periodontal ligament surface areas, and volume which are two- and three-dimensional indices.

Loss of attachment of root due to periodontal diseases can result in major loss in the surface area of attachment. Decrease in the height of attachment to the root by one-half resulted in $60.6 \%$, to $61.5 \%$ of the actual attachment area to the root (Shillingburg et al., 1997; Yamamoto et al.). 
Thus a loss of root height by one half left only $38 \%$ of the remaining root surface area although this relationship is not directly proportional (Rosenstiel et al., 2000). Therefore, the estimation of total remaining periodontal bone support provides more accurate information than the linear crown to root ratio, which is limited even in the prediction of the prognosis of a teeth (Grossmann \& Sadan).

In our study we measured the crown-to-root ratios in surface area and volume along with crown-to-root ratio using a 3D measuring method. The interrelationship among the crown-to-root ratios in length, surface area and volume were found to be $0.65,0.98$ and 1.25 , respectively. Relevance and regression analyses revealed a second-order correlation among the three crown-to-root ratios, with an R- square value of 0.96 . We observed a definite mathematical relationship among the three crown-to-root ratios.

Recently it was reported that the analysis of viscoelasticity of the PDL enables a better understanding of the biomechanical features of the key regulator tissue for tooth movement based on 3D CT evaluation. Although our study emphasizes the importance of PDL volume and surface area measurement in tooth function, correlating the data with functional studies would have established a clear relationship between these parameters and tooth function.

There is a close relation among the length, surface area and volume of crown and root of premolars. Mathematical relationship exists among the crown-to-root ratios in length, surface area and volume. 3D measuring methods and use of multiple indexes can give a better assessment of tooth function in future.

\section{ACKNOWLEDGEMENTS}

This work was supported by the Beijing City Science and Technology Plan of Nova ( ${ }^{\circ}$ Z141100002114031).

LIU, L.; LI, H.; ZHAO, T.; GAO, Y.; GUO, J.; WANG, X. \& LI, X. Relaciones de la corona y raíz dentaria en términos de longitud, superficie y volumen: Un estudio piloto de dientes premolares. Int. J. Morphol., 34(2):465-470, 2016.

RESUMEN: El objetivo de este estudio fue construir imágenes tridimensionales (3D) de los dientes premolares para medir la longitud, superficie y volumen de la corona y raíz, junto con analizar la relación matemática entre las proporciones de la corona a la raíz en términos de longitud, superficie y volumen. Veinticinco premolares fueron escaneados mediante microtomografía computadorizada (microTC) in vitro para construir modelos en 3D. Con el software Geomagic se determinaron el eje y la unión amelo-cementaria de cada diente, y se midieron la longitud, superficie y volumen de la corona y la raíz de los dientes premolares. Con el programa SPSS se calcularon y analizaron las proporciones de la corona a la raíz en términos de longitud, superficie y volumen y la relación entre la longitud, superficie y volumen de la corona y de la raíz. La interrelación entre la longitud de la corona (x), superficie (y) y el volumen (z) puede ser expresado como z= $808,20+124,80 x+3,35 y-5,59 x^{2}-0,14 x y+3.47 y^{2 * 10}-4\left(R^{2}=0,99\right)$ y la de longitud de la raíz $\left(x_{1}\right)$, área de superficie $\left(\mathrm{y}^{1}\right)$ y el volumen $\left(\mathrm{z}_{1}\right)$, como $\mathrm{z}_{1}=-207,50+13.87 \mathrm{x}_{1}+1.75 \mathrm{y}_{1}+5.03 \mathrm{x}_{1}{ }^{2} * 10-2-8.05 \mathrm{x}_{1} \mathrm{y}_{1} * 10^{-2}+2,58 * 10^{-3} \mathrm{y}_{1}^{2}\left(\mathrm{R}^{2}=0,93\right)$. La correlación entre la relación de corona a raíz en longitud $\left(\mathrm{x}_{2}\right)$, la relación corona a raíz en superficie $\left(\mathrm{y}_{2}\right)$ y la relación corona a raíz en volumen $\left(\mathrm{Z}_{2}\right)$ podría expresarse en $\mathrm{z}^{2}=-4,48$ $* 10^{-2} * 10^{-2}-1.25 \mathrm{x}^{2}+1.20 \mathrm{y}_{2} 3.29 \mathrm{x} 22-5.05 \mathrm{x}_{2} \mathrm{y}_{2}+2.00 \mathrm{y}_{2}^{2}\left(\mathrm{R}^{2}=0,96\right)$. La longitud, superficie y volumen de la corona y la raíz de los dientes premolares comparten una estrecha relación, mientras que, una relación matemática definida se pudo observar entre sus proporciones. La relación entre la corona y raíz en términos de longitud, superficie y volumen, puede proporcionar un nuevo método multi-criterio para evaluar la función de los dientes.

\section{PALABRAS CLAVE: Bicúspide; Corona del diente; Raíz del diente.}

\section{REFERENCES}

The glossary of prosthodontic terms. J. Prosthet. Dent., 94(1):1092, 2005.

Anderson, R. W.; McGarrah, H. E.; Lamb, R. D. \& Eick, J. D. Root surface measurements of mandibular molars using stereophotogrammetry. J. Am. Dent. Assoc., 107(4):613-5, 1983.

Dunlap, R. M. \& Gher, M. E. Root surface measurements of the mandibular first molar. J. Periodontol., 56(4):234-8, 1985.
Gher, M. W. Jr. \& Dunlap, R. W. Linear variation of the root surface area of the maxillary first molar. J. Periodontol., 56(1):39-43, 1985.

Greenstein, G. \& Cavallaro, J. S. Jr. Importance of crown to root and crown to implant ratios. Dent. Today, 30(3):61-2, 4, 66 passim; quiz 71, 60, 2011.

Grossmann, Y. \& Sadan, A. The prosthodontic concept of crown-to-root ratio: a review of the literature. J. Prosthet. Dent., 93(6):559-62, 2005. 
Hölttä, P.; Nyström, M.; Evälahti, M. \& Alaluusua, S. Root-crown ratios of permanent teeth in a healthy Finnish population assessed from panoramic radiographs. Eur. J. Orthod., 26(5):491-7, 2004.

Klock, K. S.; Gjerdet, N. R. \& Haugejorden, O. Periodontal attachment loss assessed by linear and area measurements in vitro. J. Clin. Periodontol., 20(6):443-7, 1993.

Melsen, B. Tissue reaction to orthodontic tooth movement--a new paradigm. Eur. J. Orthod., 23(6):671-81, 2001.

Nyman, S. R. \& Lang, N. P. Tooth mobility and the biological rationale for splinting teeth. Periodontol. 2000, 4:15-22, 1994.

Pan, J. H.; Chen, S. K.; Lin, C. H.; Leu, L. C.; Chen, C. M. \& Jeng, J. Y. Estimation of single-root surface area from true thickness data and from thickness derived from digital dental radiography. Dentomaxillofac. Radiol., 33(5):312-7, 2004.

Rosenstiel, S. F.; Land, M. F. \& Fujimoto, J. Contemporary Fixed Prosthodontics. $3^{\text {rd }}$ ed. St. Louis Mo., Elsevier, 2000.

Shillingburg, H. T.; Hobo, S.; Whitsett, L. D.; Jacobi. R. \& Brackett, S. E. Fundamentals of Fixed Prosthodontics. 3rd ed. Chicago, Quintessence Pub. Co., 1997.

Storey, E. The nature of tooth movement. Am. J. Orthod., 63(3):292314, 1973.

Yamamoto, T.; Kinoshita, Y.; Tsuneishi, M.; Takizawa, H.; Umemura, O. \& Watanabe, T. Estimation of the remaining periodontal ligament from attachment-level measurements. J. Clin. Periodontol., 33(3):221-5, 2006.

\author{
Correspondence to: \\ Hongbo Li \\ The People's Liberation Army General Hospital \\ Department of Stomatology \\ Beijing 100853 \\ CHINA
}

Email: lihongbo20151012@sina.com

Received: 03-11-2015

Accepted: 06-04-2016 